Acta vet. scand. $1981,22,246-259$.

From the Department of Internal Medicine I, Veterinary College of Norway, Oslo.

\title{
ANTIGEN-ANTIBODY CROSSED ELECTRO- PHORETIC STUDIES \\ AND QUANTITATIVE COMPARISONS OF SERUM TRANSFERRIN TYPES IN HORSES
}

By

Nils $E k$

EK, NILS: Antigen-antibody crossed electrophoretic studies and quantitative comparisons of serum transferrin types in horses. Acta vet. scand. $1981,22,246-259$. - Selected transferrin phenotypes from 14 horses were investigated by antigen-antibody crossed electrophoresis. Horse sera were subjected to starch gel electrophoresis followed by right angle electrophoresis in agarose gels containing rabbit produced anti-horse transferrin. This technique gave an additional zone in the front as compared with 2 transferrin zones seen after ordinary starch gel electrophoresis.

Comparisons of transferrin concentrations in horse sera were performed by an immunodiffusion technique. Values were related to a chosen reference serum. A total of 372 horses (210 Norwegian Trotters and 162 Warmblood Trotters) were investigated. There were considerable variations among horses, with the highest transferrin value $196 \%$ and the lowest $55 \%$ of the standard.

There were highly significant differences between average values of certain transferrin phenotypes, the highest being TfFF and the lowest TfDO, TfFO and TfRR. In animals with the same transferrin phenotype, the average transferrin values were significantly higher in foals than in mares.

No difference in transferrin values were found between sexes.

horse serum; transferrin phenotypes; relative transerrin quantities.

Transferrin or siderophilin, an ironbinding $\beta_{1}$-globulin, was first discovered in human serum by Holmberg \& Laurell (1945).

Using a starch gel technique, Ashton (1958) observed three types in the beta-globulin system in horse serum.

Braend \& Stormont (1964) found 16 beta-globulin phenotypes, identified as transferrins (Tf) in horses. These phenotypes were explained by 6 codominant alleles, $T f^{\mathrm{D}} T f^{\mathrm{F}}, T f^{\mathrm{H}}, T f^{\mathrm{M}}$, 
$T f^{O}$ and $T f^{R}$, each of which controlled 2 bands on starch gels, a relatively broad band followed by a narrow band.

The purpose of the work reported in the present article was to study some of the transferrin phenotypes by antigen-antibody crossed electrophoresis and to undertake quantitative studies of the various transferrin phenotypes.

\section{MATERIALS AND METHODS}

Sera from 14 horses were investigated by antigen-antibody crossed electrophoresis. At least 2 samples of each of the homozygous phenotypes TfDD, TfFF, TfRR and the heterozygous phenotypes TfDF, TfFR and TfHR were represented.

Sera from 372 horses, selected according to transferrin phenotypes, were quantitated by Mancini et al.'s (1965) immunodiffusion technique. The material consisted of 107 adult mares and 265 foals aged 2 to 12 months. The mares consisted of 89 Norwegian Trotters and $18 \mathrm{Warmblood}$ Trotters, and the foals of 121 Norwegian Trotters and 144 Warmblood Trotters.

The samples were obtained in connection with routine parentage control. On arrival at the laboratory, serum was separated and stored at $-20^{\circ} \mathrm{C}$.

Determination of transferrin phenotypes was done by starch gel electrophoresis.

The buffer system for the electrode vessels was: $0.3 \mathrm{~mol} / \mathrm{l}$ boric acid and $0.1 \mathrm{~mol} / \mathrm{l}$ sodium hydroxide, $\mathrm{pH} 8.6$ and for the gels : $0.005 \mathrm{~mol} / \mathrm{l}$ citric acid and $0.015 \mathrm{~mol} / \mathrm{l}$ Sigma 7-9 (tris), pH 6.5.

Connaught's starch (Connaught Laboratories Ltd., Willowdale, Ontario, Canada) at a concentration of $10 \%$ was used to prepare the gels. The serum samples were run at a voltage gradient of $10 \mathrm{~V} / \mathrm{cm}$ for about $2 \mathrm{~h}$ on gels measuring approximately $20 \times 15 \times 0.6 \mathrm{~cm}$.

\section{Preparation of the transferrin fraction}

A sample of horse serum TfRR $(20 \mathrm{ml})$ was precipitated with $0.4 \%$ rivanol $(70 \mathrm{ml}, \mathrm{pH} 9.4)$ as described by Kistler et al. (1960). The supernatant was then concentrated to about $20 \mathrm{ml}$ and precipitated with $40 \%$ saturated ammonium sulphate. The supernatant was dialysed against isotonic saline for $24 \mathrm{~h}$ and concentrated to about $20 \mathrm{ml}$. 
A sample of this solution $(2 \mathrm{ml})$ was absorbed into a double $13 \times 0.5 \mathrm{~cm}$ strip of filter paper about $1 \mathrm{~mm}$ thick and subjected to electrophoresis on starch gel. Immediately after the run, a strip about $1 \mathrm{~cm}$ broad containing the main transferrin zone was cut out of the gel. A gel treated similarly and stained with Amido Black was used as a marker for the position of the Tf zone. The strip was cut into pieces of about $1 \times 1 \mathrm{~mm}$ and suspended in $5 \mathrm{ml}$ phosphate buffer $0.05 \mathrm{~mol} / \mathrm{l}, \mathrm{pH} \mathrm{7.4}$. The suspension was then homogenized. The final volume was about $10 \mathrm{ml}$.

\section{Preparation of antiserum}

Antiserum against transferrin was prepared by immunizing a rabbit with the suspension. The rabbit was given $10 \mathrm{ml}$ of the suspension, $2.5 \mathrm{ml}$ being injected subcutaneously at 4 different sites on each occasion. The first 2 immunizations were given with a 10 day interval followed by 8 immunizations at weekly intervals. Thirty $\mathrm{ml}$ of blood was drawn from the ear vein one week after the last immunization.

The antiserum was tested by immunoelectrophoresis against horse serum as previously described (Ek 1974).

Five $\mu \mathrm{Ci}$ of $\mathrm{Fe}^{59}$ ferric citrate (Institutt for Energiteknikk, $\mathrm{Kjeller}$, Norge) was incubated for $15 \mathrm{~min}$ at $37^{\circ} \mathrm{C}$ with $0.2 \mathrm{ml}$ horse serum at $\mathrm{pH}$ 8.2. After immunoelectrophoresis against anti-transferrin serum and anti-horse serum the glass slide was put on an X-ray film (Kodirex) for $24 \mathrm{~h}$.

\section{Antigen-antibody crossed electrophoresis}

A $20 \mu \mathrm{l}$ sample of horse serum was absorbed to a $1.0 \times 0.5 \mathrm{~cm}$ strip of filter paper about $0.5 \mathrm{~mm}$ thick and subjected to electrophoresis on starch gel. Antigen-antibody crossed electrophoresis was carried out as previously described ( $E k$ 1979) using $5 \%$ antitransferrin serum in the agarose gels.

\section{Quantitation of the transferrin}

Quantitation of the transferrin was performed using the method of Mancini et al, (1965) and as described previously for Pr protein ( $E k \&$ Braend 1980). The concentration of anti-transferrin serum in the agarose gels was $15 \%$.

TfRR horse serum diluted $1 / 4,1 / 8$ and $1 / 16$ was used as a standard. The standard serum came from a 4 year old Norwegian 
Trotter mare. The 1/8 dilution was used as the reference serum. The remaining 9 wells in the agarose plate were filled with a 1/8 dilution of serum from horses to be examined.

A standard curve using the dilutions 1/4, 1/8 and 1/16 of the reference TfRR serum was prepared for each agarose plate. The quantity of transferrin was determined as a percentage of the standard by correlating the precipitate area for each serum sample to that of the standard.

The precision of the method was determined by calculation of the standard deviation of results of duplicate analyses of all the samples, according to the formula $s=\sqrt{\frac{d^{2}}{2 n}}$ where $d$ is the difference between the double test values and $n$ the number of double tests, the values being expressed as percentages of the reference serum. The standard deviation of all duplicate analyses was \pm 1.9. Conventional calculations were used for other statistical evaluations.

\section{Electrophoresis on agarose gel}

Sera from 4 horses with Tf phenotypes TfFF, TfRR, TfFR and TfFO were subjected to agarose gel electrophoresis $(20 \mathrm{~V} / \mathrm{cm})$ in a $1 \mathrm{~mm}$ thick layer of gel made with conventional barbital buffer on a glass plate ( $\mathrm{pH} \mathrm{8.6)}$. The gel was dried in a stream of air and stained with Amido Black. The dry, clear membrane was scanned in a Beckman Model R-115 apparatus according to the Instruction Manual.

Total protein in the 4 serum samples was determined using a refractometer (Bausch \& Lomb Serum Protein Meter).

The 4 serum samples were subjected to immunofixation on agarose gel according to the method of Ritchie \& Smith (1976) using anti-transferrin serum.

\section{Determination of the molecular weight}

The transferrin molecular weight (mol.wt.) was determined using the method of Whitaker (1963). Serum $(0.5 \mathrm{ml})$ from each of the 3 Tf phenotypes TfFF, TfRR and TfFR was applied to a Sephadex G-100 column $(0.9 \times 60 \mathrm{~cm})$ with $0.015 \mathrm{~mol} / \mathrm{l}$ phosphate buffer $\mathrm{pH}$ 7.4. One $\mathrm{ml}$ fractions were collected. The quantity of transferrin in each fraction was determined by the Mancini test. Catalase (mol.wt. 292,000), bovine albumin (mol.wt. 70,000) and pepsin (mol.wt. 35,500) were used as reference proteins. 


\section{RESULTS}

The transferrin antiserum obtained from the rabbit produced a single precipitation line on immunoelectrophoresis against horse serum (Fig. 1). Proof that the antiserum precipitated a serum protein which binds iron is also presented in Fig. 1.

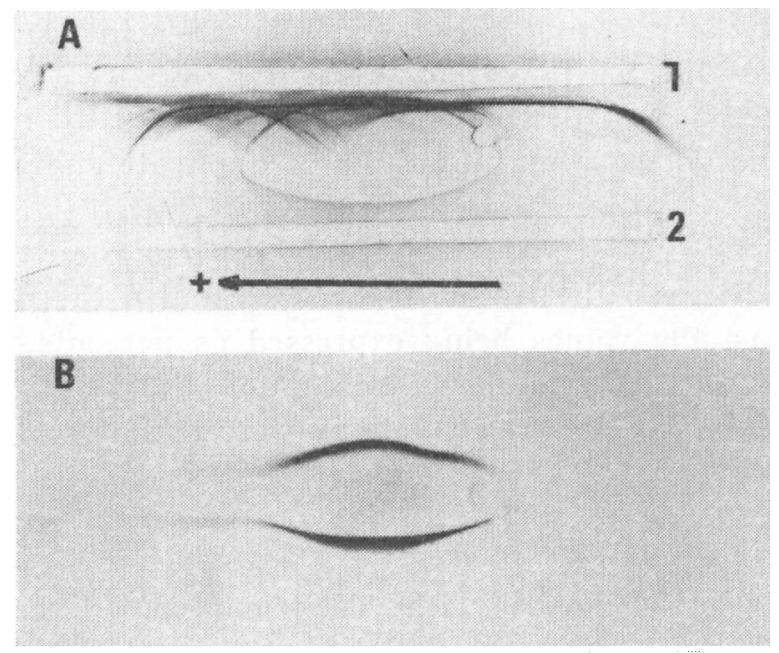

F i g u r e 1. A : Photograph of a stained agarose gel in which immunoelectrophoresis of normal horse serum against antihorse serum and anti-transferrin serum has been performed.

Well: Normal horse serum

Trough 1: Anti-horse serum

Trough 2: Anti-transferrin serum

B: Photograph of X-ray film. The film has been exposed for $24 \mathrm{~h}$ on an agarose gel in which immunoelectrophoresis of horse serum incubated with $\mathrm{Fe}^{59}$ ferric citrate, has been performed. The same antisera were used as in gel A.

Peak patterns of transferrin phenotypes are shown in Fig. 2. The transferrin homozygotes appeared with a total of 3 peaks, numbered 1 to 3 . There was one large and one small peak cor-

F i g u r e 2. Photographs of stained agarose gels after antigen-antibody crossed electrophoresis of horse sera representing six transferrin phenotypes. The anti-horse transferrin serum in the agarose gels was diluted 1:20. Initial separation was performed by starch gel electrophoresis. The lower part of each photograph shows the stained gel after starch gel electrophoresis. The upper part shows the stained agarose gel after right angle electrophoresis with peaks numbered according to the migration rate. 

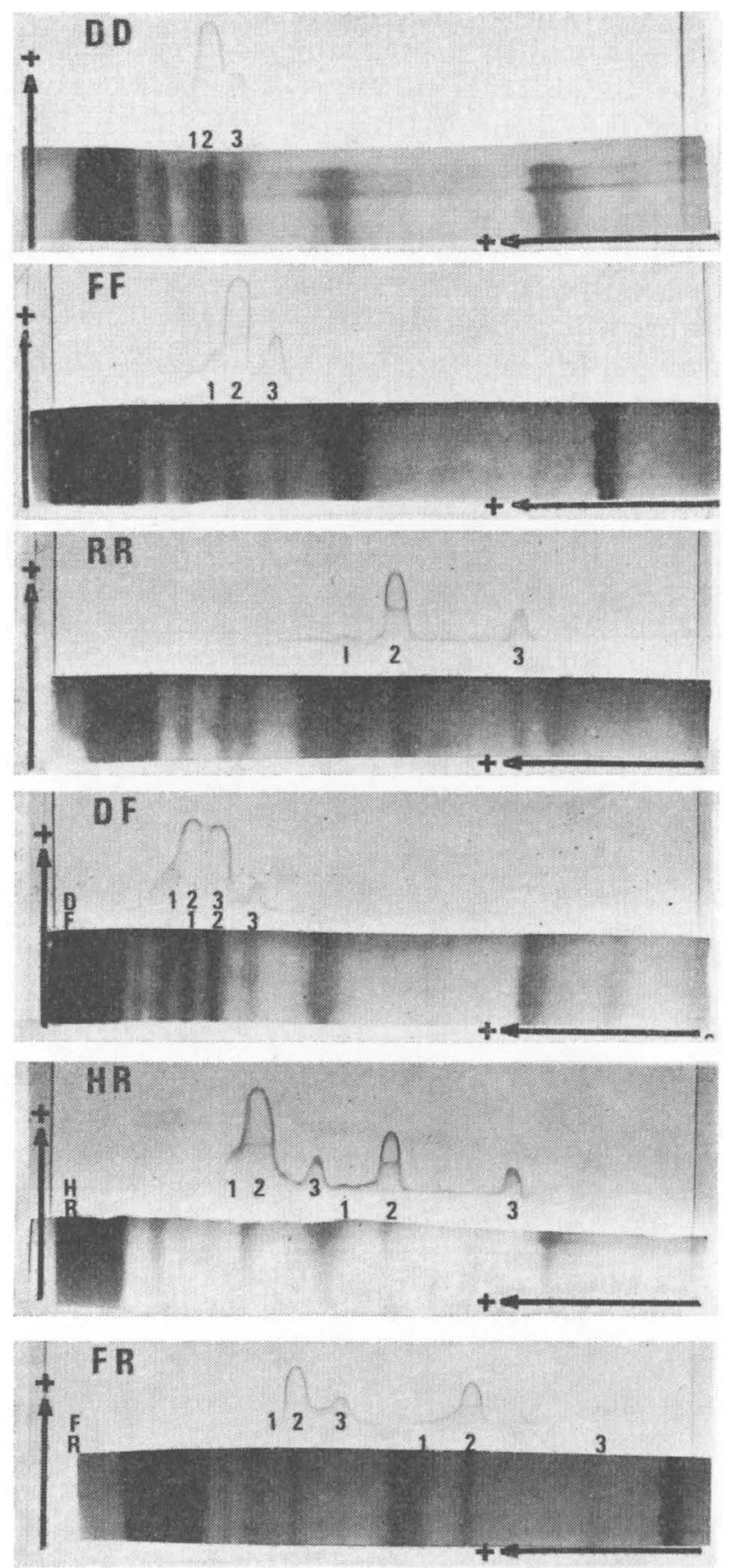
responding to the two-band-pattern described by Braend \& Stormont (1964). In addition there was a small peak in the front of the large one. In the TfRR phenotype these peaks were separated while in the TfFF- and TfDD-phenotypes the small peak appeared as an asymmetry on the largest peak.

The 3 heterozygous phenotypes appeared as combinations of the corresponding homozygous peak patterns. In the phenotype TfDF the peaks overlapped, giving fewer peaks.

Results from investigations of transferrin concentrations in adult mares and in foals aged up to 12 months, selected according to transferrin phenotypes and breeds, are presented in Table 1.

Table 1. Relationships between transferrin phenotypes and transferrin concentrations are given in percentages of the value of a reference serum from a TfRR horse.

\begin{tabular}{|c|c|c|c|c|c|c|c|}
\hline & $\begin{array}{l}\text { Category } \\
\text { of horses }\end{array}$ & Breed & $\begin{array}{c}\text { Age in } \\
\text { months }\end{array}$ & $\begin{array}{c}\text { Number } \\
\text { of horses }\end{array}$ & $\begin{array}{c}\text { Transferr } \\
\text { type }\end{array}$ & $\begin{array}{l}\text { rin Transferrin } \\
\text { concentration }\end{array}$ & $\begin{array}{l}\text { Standard } \\
\text { deviation }\end{array}$ \\
\hline $\mathbf{A}$ & Mare & WT & $>48$ & 18 & DD & 115.3 & 12.4 \\
\hline B & Mare & NT & $>48$ & 30 & FF & 129.7 & 24.3 \\
\hline C & Mare & NT & $>48$ & 29 & RR & 78.8 & 14.3 \\
\hline D & Mare & NT & $>48$ & 30 & FR & 80.3 & 9.5 \\
\hline $\mathrm{E}$ & Foal & WT & $2-11$ & 30 & DD & 136.5 & 19.3 \\
\hline $\bar{F}$ & Foal & NT & $2-10$ & 30 & FF & 153.4 & 16.5 \\
\hline G & Foal & WT & $2-12$ & 30 & FF & 147.7 & 23.5 \\
\hline H & Foal & NT & $3-10$ & 32 & $\mathbf{R R}$ & 104.3 & 14.0 \\
\hline I & Foal & WT & $2-12$ & 28 & DF & 140.3 & 21.8 \\
\hline $\mathbf{J}$ & Foal & NT & $2-12$ & 30 & FH & 150.7 & 18.9 \\
\hline $\mathbf{K}$ & Foal & WT & $3-12$ & 26 & DO & 88.9 & 12.6 \\
\hline $\mathbf{L}$ & Foal & WT & $3-12$ & 30 & FO & 93.1 & 9.2 \\
\hline M & Foal & NT & $3-12$ & 29 & FR & 114.7 & 12.8 \\
\hline \multicolumn{8}{|c|}{ Comparisons } \\
\hline \multicolumn{2}{|c|}{$\begin{array}{c}A-E \\
P<0.001\end{array}$} & $\begin{array}{c}\text { B-C } \\
\mathrm{P}<0.001\end{array}$ & $\begin{array}{c}\text { B-F } \\
P<0.001\end{array}$ & \multicolumn{2}{|c|}{ E-G } & $\begin{array}{c}\text { F-H } \\
P<0.001\end{array}$ & F-G \\
\hline
\end{tabular}

For Norwegian Trotter mares the transferrin value was significantly higher in TfFF animals when compared to TfRR mares. A similar difference was found between TfFF and TfRR 
foals. There was no significant difference between Warmblood Trotter TfFF and TfDD foals.

Norwegian Trotter TfFF foals did not differ significantly from Warmblood Trotter TfFF foals. There were also no differences between homozygous TfFF foals and heterozygous TfFH foals within the same breed.

Warmblood Trotter TfDD foals had significantly higher transferrin values than TfDD mares. This was also the case for Norwegian Trotter TfFF and TfRR foals when compared with mares which had corresponding phenotypes (Table 1 ).

Transferrin values in foals classified according to sex are given in Table 2.

T a b l e 2. Relationships between transferrin concentration and sex in foals.

\begin{tabular}{|c|c|c|c|c|c|}
\hline Sex & $\begin{array}{l}\text { Number } \\
\text { of horses }\end{array}$ & Breed & $\begin{array}{c}\text { Transferrin } \\
\text { type }\end{array}$ & $\begin{array}{l}\text { Transferrin } \\
\text { concentration }\end{array}$ & $\begin{array}{r}\text { Standard } \\
\text { deviation }\end{array}$ \\
\hline$\widehat{o}$ & 17 & NT & FF & 155.2 & 19.0 \\
\hline ㅇ & 10 & NT & FF & 151.5 & 12.1 \\
\hline$\widehat{O}$ & 17 & WT & FF & 144.6 & 25.5 \\
\hline 우 & 10 & WT & FF & 149.9 & 23.5 \\
\hline$\hat{\sigma}$ & 13 & WT & DD & 138.9 & 25.0 \\
\hline 우 & 15 & WT & DD & 132.4 & 13.4 \\
\hline$\delta$ & 15 & NT & $\mathrm{RR}$ & 106.6 & 13.7 \\
\hline 우 & 17 & NT & RR & 102.3 & 14.4 \\
\hline$\hat{\sigma}$ & 15 & WT & DF & 135.3 & 25.3 \\
\hline ㅇ & 13 & WT & DF & 145.9 & 16.1 \\
\hline$\hat{\sigma}$ & 15 & NT & FR & 115.7 & 10.8 \\
\hline 우 & 12 & NT & FR & 113.7 & 16.3 \\
\hline$\delta$ & 9 & NT & FH & 151.4 & 23.3 \\
\hline 운 & 17 & NT & FH & 152.2 & 18.3 \\
\hline$\hat{\sigma}$ & 17 & WT & FO & 92.8 & 8.6 \\
\hline q & 12 & WT & FO & 92.9 & 10.4 \\
\hline
\end{tabular}

NT = Norwegian Trotter $\mathrm{WT}=$ Warmblood Trotter

There were no differences between sexes with regard to the amount of transferrin.

Fig. 3 shows two stained parallel agarose gels after electrophoresis of sera from $4 \mathrm{Tf}$ phenotypes. On the gel marked B immunofixation was performed by adding anti-transferrin serum to the gel after electrophoresis. Only the main transferrin bands are visible on this gel. Their positions are confirmed in gel $\mathbf{A}$. 


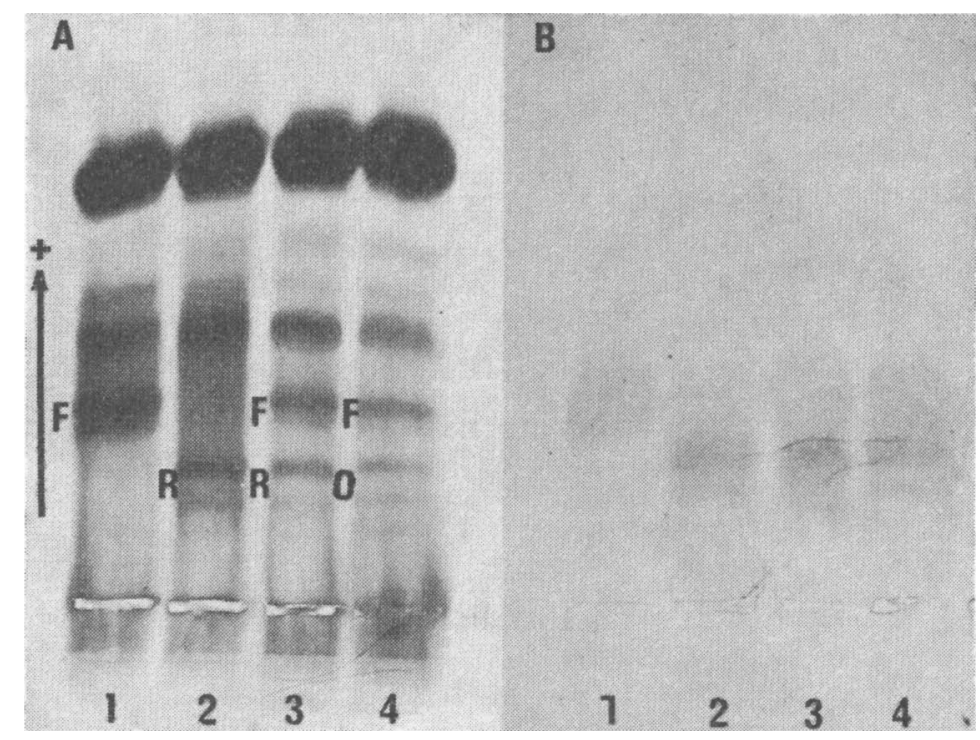

Figure 3. A: Photograph of a stained agarose gel after electrophoresis of 4 samples of horse sera $(10 \mu \mathrm{l})$. 1. TfFF, 2. TfRR, 3. TfFR and 4. TfFO. The electrophoresis was performed in a $1 \mathrm{~mm}$ thick layer of agarose gel on a glass plate $(20 \mathrm{~V} / \mathrm{cm})$ with conventional barbital buffer ( $\mathrm{pH} \mathrm{8.6)}$.

B: Photograph of a stained agarose gel with the same serum samples. After the electrophoresis of the sera $(1: 10), 0.3 \mathrm{ml}$ of anti-transferrin serum was applied on the surface of the gel for $1 \mathrm{~h}$. The gel was then washed in saline overnight, dried and stained with Amido Black.

Scanning curves of the 4 serum samples on the gel to the left (A) in Fig. 3 can be seen in Fig. 4. The value of TfFF serum was about double that of TfRR serum, and is in accordance with the results arrived at by the Mancini test. In addition the F-bands contained more protein than the R- and O-bands when judged subjectively.

No differences in molecular weight were found when sera from each of the three Tf phenotypes TfFF, TfRR and TfFR were applied to gel filtration on a column of Sephadex G-100, with the highest transferrin level appearing at the same fraction number. The molecular weight was calculated to be about 70,000 . 

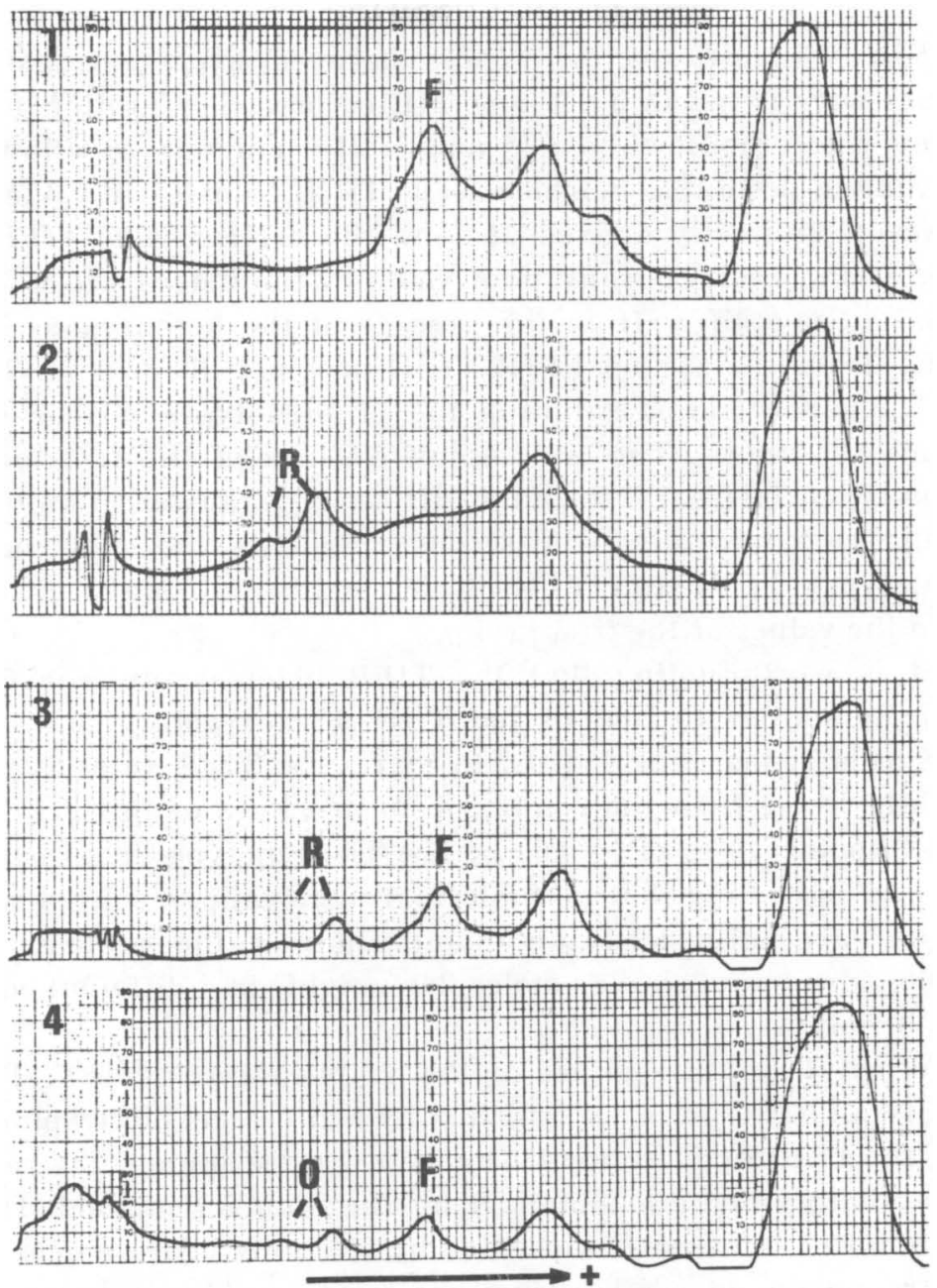

F i g u r e 4. Photographs of scanning curves of the 4 serum samples on gel $A$ in Fig. 3. The peaks of the different transferrin alleles are marked. The calculated values of transferrin protein are given below compared with the figures obtained with the Mancini method.

1. TfFF: Scanned value: $14.9 \mathrm{mg}$ per ml Mancini: $150 \%$

2. TfRR: $\quad-\quad-9.2 \quad-\quad-\quad-\quad-\quad 75 \%$

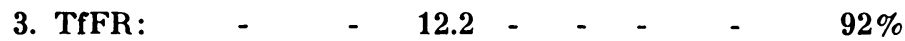

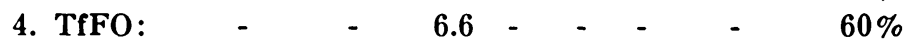




\section{DISCUSSION}

Highly significant differences between average transferrin values were found in TfFF and TfRR Norwegian Trotter horses. There were too few homozygous TfHH animals to allow the drawing of definite conclusions. The TfHH transferrin value was, however, indirectly arrived at from the heterozygous TfFH. As long as the average transferrin value of the heterozygous TfFH foals did not differ from the average of the homozygous TfFF foals, it may be assumed that TfHH does not differ from TfFF.

The concentration values of the Tf phenotypes may be divided into 2 groups. The first group consists of the fast moving phenotypes TfDD, TfFF and TfHH having transferrin values of about the same range, the second comprises the slow moving phenotypes TfOO and TfRR which are significantly different from the values of the first group.

It is worth noting that the TfFR heterozygote transferrin value is similar to that of the TfRR homozygotes. This is the case in both mares and foals. In mares the TfFR value is significantly lower than the combined mean values of the TfFF and TfRR homozygotes $(P<0.025)$. The $T f$ phenotypes had the same mol.wt., indicating that no molecular aggregations existed which might have influenced the quantitation of the protein. Baer (1968) also found similar molecular weights in 4 different equine Tf phenotypes.

When 4 serum samples of the Tf phenotypes, TfFF, TfRR, TfFR and TfFO were investigated by agarose gel electrophoresis and the transferrin content determined by scanning, the results were similar to those obtained by the Mancini method. Determination of the transferrin value by scanning agarose gels after electrophoresis of whole serum has, however, been considered to be an inaccurate semiquantitative method since complete separation into pure protein fractions is not achieved. The present investigation, however, supports the existence of differences between Tf phenotypes found by the Mancini method. Yokohama et al. (1980) also investigated serum transferrin types in horses using an immunological technique and found great variations among phenotypes. No comparisons with these results have been attempted, since a different nomenclature of the Tf phenotypes was used.

Besides the variation in the amounts of transferrin between phenotypes, there was also a significant difference between foals 
and adult mares. This was particularly evident in TfDD-, TfFFand TfRR-animals. Makimura et al. (1975) measured the transferrin content in equine sera and reported no significant changes with age, but did not take the phenotypes into consideration. Thoren-Tolling \& Martinsson (1974) found an increase in the concentration of serum transferrin in piglets up to the age of about 6 weeks. At this time the concentration was higher than that of the mothers.

In addition to the variation associated with transferrin phenotypes and age, the present study showed variations between individual horses. It is known that infections and liver cirrhosis are associated with a decrease of serum transferrin, whereas anaemias bring about an increase (Thoren-Tolling 1977). It is possible that subclinical disease conditions at the time of bleeding could explain some of the individual variation.

Although significant differences have been found between phenotypes and significant changes noticed with age, the variation in transferrin concentration may not be of physiological importance for the function of transferrin, since only one third of the iron binding capacity is usually utilized (Thoren-Tolling 1977).

The cause of the differences in serum concentration between transferrin phenotypes can only be a matter of speculation. Quantitative differences associated with phenotypes have also been found in the human Pi protein (Fagerhol 1969) and in the equine $\mathrm{Pr}$ protein ( $E k \&$ Braend 1980). The $\mathrm{Pi}$ protein content in the blood of human $\mathrm{Pi} Z Z$ subjects is only 15 per cent, and in Pi SS 60 per cent, of that normally found in Pi MM. Laurell et al. (1977) and Jeppson et al. (1978) found differences in the catabolic rate between the $\mathrm{Pi}$ types $\mathrm{MM}, \mathrm{ZZ}$ and $\mathrm{SS}$ in man. The differences, however, were too small to explain the low protein content in blood of $\mathrm{Pi} S \mathrm{SS}$ and especially in $\mathrm{Pi} \mathrm{ZZ}$. The $\mathrm{Pi} Z \mathrm{ZZ}$ protein may accumulate intracellularly in the liver cells with only small amounts escaping by passive diffusion (Bell \& Carrell 1973). Thus it seems that several processes may influence the human $\mathrm{Pi}$ protein content in blood. No equine transferrin phenotype is found which could be compared with the $\mathrm{Pi} Z Z$ type in man, but there are significant differences between fast and slow moving types. It is possible that corresponding relationships exist in horses and that they could explain the causes of the differences between transferrin phenotypes. 


\section{ACKNOWLEDGEMENT}

The author wishes to thank cand. med. vet. $K$. Ingebrigtsen, the Department of Pharmacology and Toxicology, Veterinary College of Norway, for his assistance with the experiments conducted with $\mathrm{Fe}^{59}$ and Dr. med. vet. M. Braend, the Department of Internal Medicine I, Veterinary College of Norway, for valuable advice and guidance during these investigations.

\section{REFERENCES}

Ashton, G. C.: Serum protein variations in horses. Nature (Lond.) $1958,182,1029-1030$.

Baer, A.: Le polymorphisme biochemique des transferrines chez le cheval. (The biochemical polymorphism of transferrins in the horse). These inaugurale. Moser \& Fils SA, Neuchatel 1968.

Bell, O.F. \& R. W. Carrell: Basis of the defect in $\alpha_{1}$-antitrypsin deficiency. Nature (Lond.) $1973,243,410-411$.

Braend, M. \& C. Stormont: Studies on hemoglobin and transferrin types of horses. Nord. Vet.-Med. 1964, 16, 31-37.

$E k, N .:$ Serum levels of the immunoglobulins $\operatorname{IgG}$ and $\operatorname{IgG}(\mathrm{T})$ in horses. Acta vet. scand. 1974, 15, 609-619.

$E k, N .:$ The characterization of equine prealbumin ( $\mathrm{Pr}$ ) proteins by antigen-antibody crossed electrophoresis. Acta vet. scand. 1979, $20,180-190$.

$E k, N$ \& M. Braend: Quantitative comparisons of acidic prealbumin (Pr) phenotypes in horses. Acta vet. scand. 1980, 21, 380-388.

Fagerhol, M. K.: Quantitative studies on the inherited variants of serum $\alpha_{1}$-antitrypsin. Scand. J. clin. Lab. Invest. 1969, 23, 97103.

Holmberg, C. G. \& C.-B. Laurell: Studies on the capacity of serum to bind iron. Acta physiol. scand. 1945, 10, 307-319.

Jeppson, J.-O., C.-B. Laurell, B. Nosslin \& D. W. Cox: Catabolic rate of $\alpha_{1}$-antitrypsin of $\mathrm{Pi}$ types $\mathrm{S}$, and MMalton and of asialylated M-protein in man. Clin. Sci. mol. Med. 1978, 55, 103-108.

Kistler, P., H. Nitschmann, A. Wyttenbach, M. Studer, Ch. Niederöst \& $M$. Mauerhofer: Humanes siderophilin: Isolierung mittels rivanol aus blutplasma und plasmafraktionen, analytische bestimmung und kristallisation. (Human siderophilin: Isolation with rivanol from blood plasma and plasma fractions, analytic determination and crystallization). Vox Sang. (Basel) 1960, 5, 403415.

Laurell, C.-B., B. Nosslin \& J.-O. Jeppson: Catabolic rate of $\alpha_{1}$-antitrypsin of $\mathrm{Pi}$ type $M$ and $Z$ in man. Clin. Sci. mol. Med. 1977, $52,457-461$.

Makimura, S., I. Tomoda \& K. Usui: Quantitative studies on immunoglobulins and transferrins in equine serum. Jap. J. vet. Sci. 1975, 37, 187-198.

Mancini, G., A. O. Carbonara \& J. F. Heremans: Immunochemical quantitation of antigens by single radial immunodiffusion. Immunochemistry 1965, 2, 235-254. 
Ritchie, R. F. \& R. Smith: Immunofixation. I. General principles and application to agarose gel electrophoresis. Clin. Chem. 1976, 22, $497-499$.

Thoren-Tolling, $K . \&$. Martinsson: On the transferrin concentration in serum of sows and growing pigs and in sow colostrum. Acta vet. scand. $1974,15,120-134$.

Thoren-Tolling, $K$. : Serumprotein variationer vid patologiska tilstånd hos hest och hund. (Serum protein variations with pathological conditions in horses and dogs). Svensk Vet.-Tidn. 1977, 29, 917-927.

Whitaker, J. R.: Determination of molecular weights of proteins by gel filtration on Sephadex. Analyt. Chem. 1963, 35, 1950-1953.

Yokohama, M., M. Kuwasima, N. Miura, M. Snoue, K. Mogi, T. Hosoda \& T. Nakajima: On normality of equine transferrin contents in general pupulation and quantitative difference of transferrin protein of normal homozygote and heterozygote with silent gene. Jap. J. zootech. Sci. 1980, 51, 336-341.

\section{SAMMENDRAG}

Undersфkelser ved antigen-antistoff krysset elektroforese og kvantitative sammenligninger av transferrin-typer i serum hos hester.

Utvalgte transferrin-typer fra 14 hester ble unders $\varnothing$ kt ved antigen-antistoff-elektroforese. Hesteserum ble unders $\varnothing$ kt ved hjelp av stivelsesgel-elektroforese etterfulgt av elektroforese på agarose gel som inneholdt antihest-transferrin fremstillet på kanin. Denne teknikk ga en ekstra sone $i$ fronten sammenlignet med to transferrinsoner som sees etter vanlig stivelsesgel-elektroforese.

Sammenligninger av transferrin-konsentrasjoner i hestesera ble utf $\varnothing \mathrm{rt}$ ved anvendelse av Mancini et al.'s immundiffusjonsteknikk. Relative verdier $\mathrm{i}$ forhold til et valgt referanseserum ble bestemt for $\mathrm{i}$ alt 372 hester (210 norske travere og 162 varmblods travere). Det var betydelig variasjon mellom hestene, den høyeste transferrinverdi var $196 \%$ og den laveste $55 \%$.

Mellom visse transferrin-fenotyper var det høysignifikante forskjeller mellom middelverdier, TfFF var den høyeste og TfDO, TfFO og TfRR de laveste. Hos dyr med samme transferrin-fenotype var middelverdiene signifikant høyere hos føll enn hos hopper.

Det ble ikke funnet noen forskjell på transferrin-verdier mellom kjønnene.

\section{(Received January 23, 1981).}

Reprints may be requested from: Nils Ek, the Department of Internal Medicine I, Veterinary College of Norway, P.O. Box 8146, Dep., Oslo 1, Norway. 